\title{
MOTHERING CELEBRITIES \\ Feminine/Feminist Agency and Subjectivity in the Auto/Biographies of an Indonesian Female Celebrity
}

\author{
Aquarini Priyatna \\ Department of Literature and Cultural Studies \\ Universitas Padjadjaran \\ aquarini@unpad.ac.id \\ Lina Meilinawati Rahayu \\ Department of Literature and Cultural Studies \\ Universitas Padjadjaran \\ lina.meilinawati@unpad.ac.id \\ Mega Subekti \\ Department of Literature and Cultural Studies \\ Universitas Padjadjaran \\ mega.subekti@unpad.ac.id
}

\begin{abstract}
This article discusses motherhood and mothering as portrayed in two auto/biographies of Krisdayanti, a prominent Indonesian female celebrity. Written at two different times and contexts, the first one largely focuses on portraying Krisdayanti in her persona as an Indonesian glamorous celebrity at her peak as it is faithfully observed in her likewise glamorous auto/ biography. The other one, presented in a much simpler book design and more straightforward narration, depicts her more as an ordinary person in her varied roles as a celebrity, a wife, a mother, a daughter, and a sister. The article takes note of the important dynamics and complexity of Krisdayanti's relationship with her mother and the significant roles that her mother plays that have shaped not only Krisdayanti's personal life but also her career. The two auto/biographies have shown how feminist mothering foster the formation of feminine/feminist agency and subjectivity that are constantly and continuously shifting and traversing. More specifically, this article suggests that the auto/biographies have enabled a space to reveal the empowering experience of motherhood and mothering which have contributed to the construction of a particular form of femininity within celebrity culture.
\end{abstract}




\section{Keywords}

celebrity auto/biography; celebrity culture; Indonesia; motherhood; mother-daughter relationship

\section{About the Authors}

Aquarini Priyatna holds a doctoral degree in gender studies and is currently an associate professor at the Department of Literature and Cultural Studies. Her research interests and publications focus on feminist cultural theory and practice, celebrity studies, feminist literary criticism, and popular culture.

Lina Meilinawati Rahayu holds a doctoral degree in theatre studies. She is an associate professor at the Department of Literature and Cultural Studies. Her research interests and publications focus on literary criticism, theater, and Indonesian language teaching for foreign learners.

Mega Subekti holds master's degree in Contemporary Literature. He is a junior lecturer at the Department of Literature and Cultural Studies. His research interests and publications focus on feminist literary criticism, Francophone literature, and cultural studies.

Kritika Kultura 33/34 (2019/2020): 199-225

(c) Ateneo de Manila University

<http://journals.ateneo.edu/ojs/kk/> 
Women's autobiographical narratives/autobiographies/biographies developed rapidly especially through the support of women's studies and feminism (Cosslett, Lury, and Summerfield; Smith and Watson; Stanley). According to Peterson, the early tradition of women's memoirs in the seventeenth century secured the feminine roles about their authors by writing of women's lives as mothers, daughters and wives, while they also disturbed the predominant tradition of masculine auto/ biographical writing.

Using these everyday artifacts from magazines, advertisements, and longer book forms that resemble celebrity diaries or scrapbooks, celebrity auto/biographies offer new forms of auto/biography. Drawing on the ephemera of mass culture and the everyday, these celebrities challenge existing ideas of traditional autobiography and establish relationality with and among other women who consume their works (e.g. books, advertisements, profiles/interviews).

Compared to the "traditional" auto/biography that narrates the life-story of usually male older people, whose lives are considered to be near "completion" and "worth-telling" mostly due to its celebration of public achievements, women's autobiographies, as Jelinek argues, differ from those of men at various levels, namely the level of the content, the level of the script, and the level of temporality. She further elaborates that men's autobiographies focus on the success stories mostly at the public sphere, idealize themselves as a form of role model, and are structured in the life narrative that is coherent, linear, harmonious, and in order. These "masculine autobiographies" are considered to be the narratives of an exemplary life (Brodzki and Schenck). Women's autobiographies, on the contrary, often detail domestic spheres and connections with other people, attempt to "authenticate themselves" through their irregular, fragmented, and formless life narratives. Though some theorists criticize the essentialist potential of her argument, it is worth noting though that these arguments put the feminist perspective of how women's auto/ biographies resist the normative autobiographies modeled by men and men's bodies.

As Smith and Watson assert, "[b]y incorporating hitherto unspoken female experience in telling their own stories, women revised the content and purposes of autobiography and insisted on alternative stories" (6). Krisdayanti, the female celebrity who documents and presents her life in the two auto/biographies selected in this article, depicts herself not so much as a role model or as the "I" who is "unified, rational, coherent, autonomous, free" (Smith and Watson), rather as a fragmented, not always linear, and not particularly stable either. In analyzing female celebrities' auto/biographical practices, such as the Cover Story, in magazines, Priyatna argues that female celebrities are presented to be "fragmented yet coherent" which reflect not only their construction of subjectivity but also the feminine narrative structure 
of the genre ("Fragments and Coherence"). Thus, the self-representation in the auto/biographies must be regarded as "a process by which subjects produced themselves as women within particular discursive context... and toward new forms of representation that disrupt those normative constructions" (Robinson 11).

The emergence of women's auto/biographies, and even feminist auto/ biographies, clearly signals a shift in the forms and types, as well as the scope of auto/biography. Within the context of popular culture, and especially the celebrity culture, celebrities' lives are constantly narrated more as lives in-progress worthy of study and attention. Bruner contends that an autobiography more than merely presents a personal expression or "inner dynamics," it serves as a cultural product as well (39).

As a media for representation, Indonesian female celebrity auto/biographies will find it difficult to escape the discussion on motherhood as they need to portray the celebrities within the construct of celebrity femininity, and motherhood is normatively perceived as a crucial part of the construction of femininity. In Indonesia, such ideology was endorsed by the New Order regime (1965-1998). The term "ibuism" was first coined by Madelon Djadjadiningrat-Nieuwenhuis and it is deeply framed within Javanese values that construct women as first and foremost the mother of her children, bearing not only the reproductive roles and responsibilities as well as domestic chores and duties. The term also suggests that Indonesian women's sexuality is framed as an "ibu" - a mother. Coupling the idea of ibuism and priyayization, Djajadiningrat-Nieuwenhuis showed how the Javanese local values pertaining to women's roles significantly contributed to the construction of a larger context of women's perceived roles within the national context (Suryakusuma).

Taking up from Djajadiningrat-Nieuwenhuis' work, Suryakusuma coined the very important term of "State Ibuism". She argues that Indonesian women's sexuality is not only structured within the personal domain but is also more broadly a state construct and founded in State Ibuism. State Ibuism particularly manifested in Panca Dharma Wanita (Five Responsibilities of Women) during the New Order. Panca Dharma Wanita was initially aimed at the wives of civil servants whose membership in KOPRI (Republic of Indonesia Civil Servants Corps) was compulsory. It constructed a woman as a wife or as a mother or as both. It ruled that "a wife is (1) to support her husband's career and duties; (2) provide offspring; (3) care for and rear the children; (4) be a good housekeeper; and (5) be a guardian of the community" (Sunindyo).

This article examines motherhood as depicted in two auto/biographies of Krisdayanti, who is among the top celebrities in Indonesia. Krisdayanti, born on 
24. March 1975, rose to fame after winning the Regional Asian singing competition Asia Bagus in 1992. Created by Fuji Television, Asia Bagus was broadcast from 1992 till 2000 in Indonesia, Singapore, Malaysia, Korea, Taiwan, and Thailand. It searched for and in so doing established emerging artists in Asia. The champion is the one that prevailed in three shows and won the monthly contest. The grand championships were held once a year in Japan. Krisdayanti was the first to win the grand championship, beating fellow Indonesian, Dewi Gita, who is now an acclaimed singer herself.

Before her singing career, Krisdayanti started working as a model after securing her position as one of the finalists of Gadis Sampul - cover girl of Gadis magazine contest. Apart from modeling and singing, she has also starred in local television programs, which proves her versatility in the entertainment industry. Her fame has brought her personal matters into the public, including her role as a mother. Krisdayanti serves as an interesting case in our investigation on the issue of celebrity motherhood. Despite the glamor of the industry, celebrity mothers are still mothers and as Kristeva outlines,

There might doubtless be a way to approach the dark area that motherhood constitutes for a woman; one needs to listen, more carefully than ever, to what mothers are saying today, through their economic difficulties, and beyond the guilt that too existentialist feminism handed down, through discomforts, insomnias, joys, angers, desires, pains, and pleasures... ("Motherhood According to Giovanni Bellini" 179)

The narratives of motherhood, we argue, will contribute to the more layered and delicate understanding that mothering entails. Within feminist studies, one of the most important works on motherhood is the book written by Adrienne Rich, Of Woman Born, published for the first time in 1976. Widely quoted, the most important argument that Rich offered is the need to differentiate motherhood as an experience and motherhood as an institution. As O'Reilly emphasizes, motherhood as an institution is a "male-defined site of oppression" (From Motherhood to Mothering 159) while motherhood as an experience is a potential source of power.

Also important is the seminal work by Nancy Chodorow, who argues that "the reproduction of mothering [is] central and [a] constituting element in the social organization and reproduction of gender" and it is more psychological than social (7). Both Rich and Chodorow underline the substantial significance of mother-daughter relationship. They argue that the normative family structure designates women in the mothering duties while men in financial-procuring ones which effectively gives way to the perpetuation of the sexual division of labor. Reproduction of mothering enables daughters to develop the ability for intimacy and human connections, but it gives rise to girls' difficulty in claiming their own interests and benefits. Chodorow 
further argues that “women's mothering reproduces itself cyclically. Women as mothers, produce daughters with mothering capacities and the desire to mother" (7). Critics have targeted Chodorow for her idea that the root of oppression against women is more psychological than social and that Chodorow's argument still very much relies on the normative family structure. They argue that Chodorow fails to acknowledge the diverse forms of family structure (Tong 146-147), thus, the diverse forms of mothering.

Following various feminist theorists on motherhood, O'Reilly extends that mother-daughter's connection and closeness is essential to female empowerment (From Motherhood to Mothering 163). This line of argument implies the feminist potential of mothering that focuses more on the mother and the daughter, and their relationship with each other, within various forms of family structure such as those families where children are raised by a single parent, namely the mother.

In her later work, O'Reilly argues that the emergence of mommy lit which bears a new ideology of motherhood ("The Motherhood Memoir"). The characteristics of this new ideology revolves around ideas that first of all, mothering is natural to women and "essential to their being", and that the mother is the central caregiver of her biological children, thus subsequently, children require full-time mothering ("The Motherhood Memoir" 206). This is resonant to the idea that good motherhood demands the full-time presence of the mothers, and in all activities deemed necessary for the children. Through this ideology, we hear things like "soccer mums," "quality time," "play, cook, read, take classes with their children."

Nevertheless, children's needs are not homogenous. As Lawler carefully elaborates, “"needs' become socially constituted” (126). Needs and how these needs are met cannot, therefore, be generalized. Needs are framed within specific contexts, culturally, socially, even geographically. As in Krisdayanti's auto/biographies, it is important to note that she was raised by a single mother along with her elder sister, Yuni Shara, who is also a celebrity in a small town called Malang in East Java. Her parents divorced and the mother and her two daughters were left in a challenging economic condition, making the mother the sole breadwinner of the family. In both auto/biographies, the reason why the parents divorced was never mentioned. The situation is only implicated but never really explicitly stated.

It also needs to be taken into perspective that Kridayanti is Javanese and Muslim, and both groups are often considered to hold a rather normative gender perspective. While the article will not specifically dwell on the issue in terms of her being Muslim, her Javanese ethnic identity comes into play as she describes her mother. The fact that she was raised by a single mother endows the need for the mother to somehow make up for the absence of the father. 
In celebrity culture, particularly in Indonesia, female celebrities are compelled to carry out a double performance of femininity (Prabasmoro) as their celebrity status requires them to perform their femininity in public. Despite the fact that the act of "meeting the needs" or caring for children is not gender specific, motherhood has been held to be the ultimate form of womanhood and femininity. Such a perspective has engendered the normative, if not endorsed, practice that mothering is a function assigned solely to women. In other words, mothering is a gendered activity with feminine attributes being considered the most important features in good motherhood.

Perceived from a feminist perspective, such opinion somehow undermines the previous feminist gains of rights and freedom to participate in the public domains. As Douglas and Michaels contend, "the new momism is a highly romanticised and yet demanding view of motherhood in which the standards for success are impossible to meet" (4). The romanticization of motherhood contributes to the sense of guilt and drawbacks among successful women, including female celebrities who are pressured to walk on the thin thread of being a public person and a mother (Douglas and Michaels).

However, the good mother image is enacted quite faithfully by Krisdayanti during the period covered by the two auto/biographies. The display of her role and identity as a wife and mother before anything else invokes Bartky's argument relating to how femininity is performed in public (Prabasmoro). Before her shocking divorce in October 2009, Krisdayanti was almost always accompanied by her husband and/ or children in her public appearances. She claims: "My children are the source of my energy" (Endah 167). She always took a big entourage consisting of her mother, her husband, her two children and the babysitters on her tours (Endah). This display can be read as an invocation of traditional family life in exceptional circumstances. Her role as a mother and wife is demonstrated as natural and ordinary. Despite her celebrity status and impossible schedule, she is shown to perform her mothering role alongside her profession flawlessly as the pictures in her first auto/biography displays.

The beautiful images of Krisdayanti with her children as well as those with her mother reveal the idyllic and ideal fantasy of motherhood and womanhood. One can also argue that the images reveal the ideal but at the same time cover the real work endowed to produce the image. Every detail of the images requires careful and elaborate procedure, if not fabrication. Also covered is the troop of helpers and assistants that has managed Krisdayanti's household and childrearing. It does show the benefit of being middle-class that has made mothering possible without impeding women from being successful in public. Her [upper] middle-class status that her career has afforded her has made her experience of mothering largely 
different from other ordinary women. Still, our stance is that her representation of mothering deserves a feminist reading as a potential feminist construction of celebrity motherhood.

Dwelling further on the potential of motherhood, an interesting perspective is offered by Lagerwey. Examining various representations of motherhood in popular culture in the US, Lagerwey argues that rather than having to play the different roles as separate, motherhood can be thought of as a beneficial element of celebrity status. As she points out motherhood is an indivisible part of the persona and self-brand of celebrities. Thus, there is a need for celebrities to portray themselves as mothers in a way that it can be translated into products and endorsements. Hollywood celebrities have been known to commodify not only their celebrity status but also their status as mothers. Motherhood in a way creates an opportunity for financial gain and power as we have seen among others in the works of Victoria Beckham, Kim Kardashian, Jessica Alba, and Beyonce as well as the various television programs featuring mother such as the Housewives series (Lagerwey).

It can be proposed that, on the one hand, this "new momism" operates as another form of institutional motherhood, the one that is actually deeply grounded in patriarchy. On another, as O'Reilly argues, motherhood can be thought of as a feminist project with the potential for social changes and transformation. She delineates how feminists have been attempting to uncover and challenge the oppressive way motherhood as an institution operates (From Motherhood to Mothering), and have tried to formulate and articulate mothering as female-defined, even feminist undertaking. Her argument is important because she further voices Rich's stance that mothers can significantly contribute to the more egalitarian social construction through child rearing. The discussion on Krisdayanti's act of mothering and her own mother's act of mothering her is to uncover the various ways mothering can act as a feminist endeavor. Fiona Green terms such practice as "feminist mothering," which we argue to be the case displayed in the two auto/ biographies of Krisdayanti.

This article suggests that mothers are instrumental in the making of their celebrity children, particularly their celebrity daughters. Following Battersby, Stone argues that "mothers exercise overwhelming power - emotionally, affectively, corporeally [...] arguably, it is because mothers... exert such emotional power within early mother-child relations that children tend to react in fear and hostility against maternal and female power" (169). This ambivalence, as Stone further explains, continues as daughters struggle for autonomy while remain identified with their mothers to assume their female identity. Nevertheless, O'Reilly has documented the varied writers who have argued that a strong mother-daughter relationship engenders "a strong female self" (From Motherhood to Mothering 163), which this 
article attempts to shows in the depiction of the relationship of Krisdayanti, along with her sister and her mother.

\section{MOTHERING CELEBRITIES}

This article offers some illustrations pertaining to the complex structure of mothering and motherhood as well as "daughtering" and how mother-daughter relationships form an important element contributing to the celebrities' status. The discussion will need to include the depiction of Krisdayanti's relationship with her sister, Yuni Shara, who is also a celebrity. In a similar gesture, Yuni Shara's auto/ biography also delineates this important sisterly relationship with Krisdayanti as well her relationship with their mother (Geraldine and Triadi). The discussion of mother-daughter relationship in the two auto/biographies of Krisdayanti will necessarily include the issue of mother-daughter relationship between Yuni Shara and her/their mother.

We have chosen two auto/biographies of Krisdayanti because they represent not only the different phases of her life but also the different outlooks of her life. Seribu Satu KD, the first auto/biography, concentrates on her stardom and celebrity status. In other words, it centers on Krisdayanti's extraordinariness while the second one, My Life, My Secret, pivots more on Krisdayanti as an ordinary person with an ordinary person's problems. Published in 2004, Krisdayanti's first auto/ biography was arguably the trendsetter of celebrity auto/biographies in Indonesia (Prabasmoro). It comes in hardcover, full color, and heavily illustrated with artistic photography. It thus radiates luxury and glamor, and reflects her Diva status. Krisdayanti claims the publication of the auto/biography was solely intended for her fans (Endah 5),

Aku akan membuat sesuatu. Sebuah buku yang bisa memuaskan penggemarpenggemarku. Di dalamnya aku akan bercerita banyak tentang karier dan hidupku. Buku yang akan menguak kehidupanku yang sebenarnya, yang tidak diketahui banyak orang

I am going to make something, a book that will satisfy my fans. In the book, I will tell many things about my career and my life. The book that will disclose my true life, the one not known to the public. ${ }^{1}$

Her statement implies her claim for truth. Still, it invokes questions and doubts, particularly regarding the depiction of her physical transformation. She vehemently denied having any cosmetic surgery following the publication of her first auto/ 
biography, but finally admitted to having some in the second auto/biography. Catatan Hati Krisdayanti: My Life, My Secret, the second auto/biography, which was also co-written by Alberthienne Endah in 2009, somehow attempts to straighten things up. Coming in so much simpler packaging, in black and white, the second auto/biography in many different ways articulates more humility and perhaps honesty.

Rather than highlighting her celebrity status, in the second auto/biography, Krisdayanti exposes her vulnerability and discloses her previously hidden truth about herself, including her body image. She even opens up about the cracks of her marriage to her then-husband, Anang Hermansyah. The second auto/biography thus provides a more nuanced portrayal of Krisdayanti, a person, rather than a diva. Particularly in the beginning of the book, the second auto/biography is dominated by the portrayal of the mother, amidst her illness. The auto/biography itself focuses more on her ups and downs in the entertainment industry which reveal the pressures and the challenges she was exposed to that were carefully maintained under cover. The second auto/biography suggests the shift of focus from Krisdayanti's glamor and success, which implies fabricated representation in the first auto/biography, to the more overt and humble depiction of her life as a person in the second. This shift thus reveals the contradictions and problems of the two auto/biographies.

The shift is markedly observable in the different approaches to the two books' designs and covers. The cover of the first auto/biography replicates the fashion magazine artistic sense with Krisdayanti wearing sophisticated high-class clothing and accessories. In the second auto/biography, Krisdayanti is wearing a more casual dress and a relatively simple makeup. Despite her looking quite well-maintained, she dons more casual looks throughout. The second auto/biography captures more of Krisdayanti's ordinariness which signifies her claim to depict a more honest representation of her everyday life, including her vulnerability and flaws.

We argue that guilt is quite strongly indicated in the second auto/biography, which deals not only with her over-romanticized representation of herself as a celebrity, but also her representation as a wife, a daughter, and a mother. The staged images in the first auto/biography suggest more of her celebrity status even with regard to the various familial relationships she claims important in the formation of her identity and sense of self. It is quite clear that in establishing herself as a celebrity, she portrays herself also as a celebrity mother, not just a mother. The depiction of the ever-harmonious familial relationships in the first auto/biography romanticizes her celebrity motherhood that is guilt-free and glorious.

In the second auto/biography, guilt is insinuated early, particularly pertaining to her position as a daughter, followed by her position as a wife. The guilt implies 
the idealized construction of motherhood and wifehood, as well as the normative expectations of being a daughter. Apart from candid family pictures scattered almost at the end of the book and a short list of notes detailing what she wishes to do, entitled "Saya masih mau [I still wish]," the second auto/biography does not give a specific part narrating Krisdayanti's relationship with her children. Out of fifteen wishes she lists, only two are actually concerned with her children, "membantu mendandani Loli setiap pagi [help dress Loli up every morning]" and "main perang-perangan sama Azriel [play war games with Azriel]." The two wishes suggest the lack of time she has managed to share with her children. At the same time, they also reflect her attempt to show that the children are on her mind and that she is trying to be the mother she is supposed to be. Due to the length and weight dedicated to the story of her work, the second auto/biography can also be considered as her attempt to amend her previous glamorized, if not fake, portrayal of herself as a celebrity by revealing the frequent conflicts and challenges she has to deal with in her position as a famous celebrity.

In this particular context of celebrity culture, such depiction of ordinariness as illustrated by her fears, her worries, her difficulties and all the ups and downs in her life engenders in adverse the representation of her extraordinariness (Dyer; Priyatna, Becoming White; Redmond). Through the unfolding of her perfect image, Krisdayanti is reestablishing her celebrity status and distinction. The depiction displays not only the glamorous celebrity but also a dedicated and loving daughter, and human being as testified by her various friends and relatives in the auto/ biography.

In the two auto/biographies, a nuanced portrayal of mothering and motherdaughter relations is presented as a crucial contributing element to female subjectivity and agency. The auto/biographies also provide some illustrations with regard to the complex structure of mothering and motherhood as well as "daughtering" and to how mother-daughter relationships form an important factor that has helped establish Krisdayanti as celebrity. This article focuses on the utterances by the auto/biographical subject through which the narrative is told and frames it within the theoretical discourse on motherhood as having been discussed.

The title "mothering celebrities" in this article refers to three frameworks. First, it refers to celebrities who are operating as a mother, thus doing the mothering. Second, it refers to the mothers of celebrities who are mothering the celebrities. Third, the term "mothering" refers to what Lawler proposes as "meeting children's needs," namely children need their mother and that mothers fulfill their children's needs (125). The implication of such an argument is that needs also suggest the mother's power and authority as she is the one who is performing the meeting 
of the needs. In short, mothering engenders power in women, the power that is actually endorsed by the society.

In the case of celebrity mothers, things may prove to be more complicated as they are constantly under scrutiny and surveillance as their lives get unfolded in public through various media, including social media. On one hand, female celebrities have more financial power to meet their children's needs. On the other hand, the way they meet their children's needs contributes to their (un)popularity and (un)likeability. As an illustration, there have been competing representations of motherhood between Krisdayanti and Ashanti, the wife of Krisdayanti's ex-husband, in which the netizens seem to be in favor of Ashanti as the better mother for Krisdayanti's two elder children. Krisdayanti is seen as less of a mother as she is considered to have left her family including her two children when she embarked on her relationship with her now present husband (Pemita). While the two mothers have established a more amicable relationship, the way these two celebrities are perceived as well as the way they represent themselves, particularly in social media, indicate the complexity of celebrity motherhood. Their identities and lives as mothers are not limited within the private and domestic domain since their celebrity status demands that they also perform their motherhood in public and as part of public discourse. Such pressure on the mothers eventually affects the children as well in a way that is more complex compared to other children who can enjoy their childhood away from the public eye.

The children of Krisdayanti's have been known to have been slammed by netizens when they publicly expressed their closeness to their stepmother and stated their compliment for their stepmother, implying their strained relationship with Krisdayanti as their biological mother (Bhisma). Paradoxically despite the pressure, having celebrity mothers also means that the children have gained public attention from the very beginning, which can be translated into their own popularity and potential financial power.

As a daughter, Krisdayanti has always proclaimed her closeness to her mother. A chapter in Krisdayanti's first auto/biography is dedicated to her mother and is entitled "Mama Inspirasiku." In this chapter, she discusses how her mother provides her with a sense of security and safety, a dependency that cannot be replaced even when she is married and having her own children. She discusses her needs to be able to play a spoiled and emotionally dependent daughter in her mother's presence, a space that functions like a shelter for her as she struggles in her public role as a celebrity, "[p]ada Mama aku menemukan rasa damai yang tiada tara" - "In my mother, I found incomparable peace" (Endah 164). Her emotional needs for her mother is depicted in such a way that her mother "can even be considered as [her] psychic" (Endah 164). The delineation hints a somewhat normative role a mother is 
supposed to play within the Indonesian New Order context, namely that a mother is supposed to be "looking after her family, a group, a class, a company, or the state, without demanding power or prestige in return" (Djajadiningrat-Nieuwenhuis 44).

However, more than just a mother who provides comfort, Krisdayanti's mother serves as a role model that represents what Paramaditha coins as "Imaginary Mother," namely a powerful mother whose place is always outside culture, representing the realm of the Imaginary" (81). Being a single mother, her mother functions both as a mother and a father. She provides her daughters not only with care and love but also livelihood. In this auto/biography, this role of earning livelihood is not considered "masculine" or that replacing the function of a father. Rather, it is depicted as a feminine strength and struggle of being a mother, "Jika ditanya, dari mana kuperoleh energi untuk bekerja. Jawabnya dari kenanganku terhadap perjuangan Mama [If you ask me, where I get all the energy to work. My answer is from the memory of my mother's struggle]" (Endah 164). While mothers are naturally expected to provide their children's livelihood, the normative standard dictates that it is a masculine duty to provide the income to meet the needs for livelihood. The fact that it is her mother that provides their livelihood poses a very interesting notion of mothering. The tone set in the two auto/biographies seems to embrace the economic ventures as motherly, not fatherly in a way that the absent role of the father is largely ignored while the mother's role is glorified. In both auto/biographies, the absence of the father is not problematized and it seems to be taken for granted that it is her mother who will be taking care of the family. More than just transgressing the sexual division of work, we find this particular instance to illustrate the complexity of motherhood where motherhood entails not only the psychological and caring support afforded by the mother within the domestic domain, but it also transcends to the public domain in a way that sexual division of work must be reconsidered to be more than mere polar notions of the public and private.

The strength as exemplified by the mother is to be perceived specifically feminine. Her independence is attributed to her being a mother. Such an arrangement does not submit to the ideas of normative femininities. In fact, the father is made completely absent from the narrative, enabling the mother-daughter relationship to be the focal point of the narratives of both auto/biographies. Neither of the two auto/biographies explicates the absence of the father. The family is portrayed to be complete and sufficient with only its three female members. Throughout the narratives, it is clear that the mother and her daughters perceive each other as constitutive of a solid team despite their obvious differences. Recollecting her rough beginning, Krisdayanti writes that her mother, her sister, and herself have become a "trio yang tak lekang oleh kegundahan rasa. Tak ada rasa pesimis, apalagi merasa kalah. Entah siapa membesarkan hati siapa, pokoknya kami begitu 
yakin dan geer bahwa kami akan sanggup bertahan di kota ini [trio that will not pervade. We were not in the least pessimistic, or feeling like we're losing. We don't know who actually encouraged who, but we were so sure and even overconfident that we would survive this city]" (57). This illustrates not only how the mother has been able to deal with the difficult situation but also how she succeeds in making her daughters independent and establish their own agency and subjectivity in the process.

The collective "we" that they use can also be argued to indicate a form of solidarity and even partnership the mother and the daughters have established over the years and throughout the difficult time that they have gone through. It can also be proposed that the absence of the father/husband provides a space for the mother and the daughters to fully explore and strengthen their "sisterhood" without the presence of the patriarch. The success is thus attributed to everyone in the family: the mother and the daughters.

Here we see how the mother-daughter relationship evolves from the position where the mother is the sole provider of their material and psychological needs to the interchangeable positions where the daughters provide the same things for the mother. As the two daughters, Krisdayanti and Yuni Shara, grew to become better known, they began to earn more for the family. The mother was no longer the provider for the daughters, as now the daughters earn the bread for the mother. What needs to be taken into account though was that the impetus of the daughters' success was the mother. It was the mother who decided to move from a small city like Malang to Jakarta simply to ensure that the daughters would have the opportunity to establish their singing careers. It was the mother's confidence in her daughters that have led to the crucial decision to move to Jakarta, and the daughters learn from the grit and strength that the mother has shown. Krisdayanti observes, "Mama sepertinya menjadi sangat kuat karena dibentuk kondisi. Selain harus banting tulang demi hidup kami, ia juga menjadi penyangga psikologis kami [Mama seems to be very strong because her condition has made her so. Apart from having to work hard to provide us, she is also the pillar for our psychological well-being]" (47). Now that the daughters have become established celebrities, her mother's role is relegated to the "psychological support" while both daughters provide the "financial/economic support" for the mother. Interestingly, the auto/ biographies do not seem to impart these now reversed-roles quite explicitly. The reversal is implicated to be natural and to be expected to happen, again showing the complexity of the mother-daughter relationship where both parties provide and accept support from each other. The mother-daughter relationship as depicted in the two auto/biographies constitutes a form of interdependency and intersubjectivity that supports feminist deconstruction of binary opposition as also shown through the portrayal of Krisdayanti's relationship with her [former] husband, discussed 
elsewhere (Priyatna, "Negotiating Celebrity Femininity in Three Auto/Biographies of Indonesian Female Celebrities").

As an entertainer, Krisdayanti is known for navigating different professional roles, each with its own specific demands. She not only sings, but also models and acts, not to mention endorses services and products. The narratives of both auto/ biographies are quite clear in suggesting that her mother's mode of mothering affects her in the way that it empowers both the mother and the daughters. As narrated, it is the mother who turns out to be the one who has taught her daughter work ethics, showing her what it means to work hard in her role as a providing mother. Krisdayanti's mother only worked at a small beauty salon located in a small alley, but she showed endurance and perseverance, working hard from dawn till dusk. The memory of her mother working very hard avails her an exemplary work ethics. It even instills the guilt in Krisdayanti whenever she does not feel like working (Endah 164). We argue that Krisdayanti's mother has been portrayed to enact a form of feminist mothering that has contributed to the establishment of her own agency and subjectivity as well as her daughters'.

The absence of the father has indeed imposed a circumstance where the mother and the two daughters have to survive on their own. It is only in her second auto/ biography that Krisdayanti somewhat details what happened to the father, that her mother and her father had a lot of fierce arguments with each other, and that one day her father left the house looking sad and carrying a big bag. Her sister was five years old at that time, and Krisdayanti was only two years old. They never saw him again afterward. It was never known what caused the subsequent divorce because they never actually brought up the question even when they became old enough to ask,

Bagi kami, sudah tak perlu lagi jawaban itu. Ada hal yang jauh lebih penting untuk kami pikirkan, yakni baaimana caranya agar kami bisa hidup dengan layak dan bisa memiliki masa depan.

We no longer need the answer. There are far more important things for us to think of, namely how to live properly and how to have a [bright] future. (Krisdayanti and Endah 46-47)

From the very beginning, "living properly" seemed to be the goal as the family used to live in a big house shared with other families. Conflicts among the families and the members of the different families have caused rifts to be frequent. Among the dreams that the sisters shared during their humble beginning was, "Seandainya kami hidup di rumah sendiri. Seadanya kami bisa menjejak Jakarta. [If only we could live in our own house. If only we could set foot on Jakarta]" (Krisdayanti 
and Endah 48). Being raised by a single mother in a more or less communal house has forged them into strong-minded persons with an iron will to succeed. The example given by their mother has not only strengthened the daughters but more importantly set the ground for them to overcome their problems and prevail. Both auto/biographies clearly define the relationship between Krisdayanti and her mother as crucial, not only to her career but also to her well-being. The mother provides a role of a strong mother that enables her daughter to be strong as well. Rich aptly contends:

As daughters we need mothers who want their own freedom and ours. We need to be the vessels of another woman's self-denial and frustration. The quality of the mother's life - however embattled and unprotected - is her primary bequest to her daughter because women who can believe in herself, who is a fighter, and who continues to struggle to create livable space around her, is demonstrating to her daughter that these possibilities exist (247).

As having been discussed, Krisdayanti's portrayal of her mother is that of a strongwilled woman. However, the image escapes the binary trap of weak and strong or strict and loose. As narrated, while the mother is depicted to be very independent and progressive, she is also presented to have the characteristics that can be considered "njawani" (very Javanese), which in this context refers to the traditional Javanese attributes of sensitivity and not being blunt and straightforward. This contributes to the complex formation of mothering where a mother navigates power and authority on one part, and sensitivity and softness on the other part. Her mother's sense of authority and sensitivity contribute to her attribution of femininity, which is what is typically considered to be Javanese women's type of strength.

Mama juga sangat mengerti bagaimana menjaga perasaanku. Jika membaca berita-berita miring tentang diriku di media massa, ia tidak langsung menelepon atau menegurku. Ia simpan baik baik koran dan tabloidnya. Lalu, jika situasinya sudah ademi, barulah dia membahasnya pelan-pelan. Setiap katanya adalah guyuran air dingin bagi jiwaku. Sikap njawani dan kehalusan kata-katanya mampu menyejukkan hatiku bila sedang dirundung masalah.

Mama understands very well how to take care of my feelings. When reading negative news about me in mass media, she doesn't immediately call me up or reprimand me. She keeps the newspaper and the tabloids. When things have cooled down, she will discuss it carefully. Every word that she utters feels like cool water for my soul. Her typically Javanese gesture and her soft words ease my heart when I am in trouble. (Endah 164, emphasis added)

Kritika Kultura 33/34 (2019/2020): 213-225 
Here it can be argued that while her mother's authority and power are accepted; the daughter is also aware that her acceptance by the mother is always granted. This reveals the safe environment that the mother and the daughter have built among themselves. Her mother represents not only the feminine attributes of caring and loving but also strength, agency and subjectivity. The mother has enacted the enabling and the empowering mode of mothering, aiming at making the daughters independent persons with her own subjectivity and agency (Lagerwey) rather than part of her mother's entity.

\section{MOTHERING THE MOTHER}

Krisdayanti's second auto/biography begins with the account of her mother suffering from a stroke, which completely weakened her highly active mother. She delineates how her mother "terbaring lemah, atau terdiam pasif [lying down weak and passively immobile]" (Krisdayanti and Endah 16). The realization of the loss of the maternal figure as she has known it invoked a strange fear and confusion, "[s]ebuah ketakutan asing yang tidak pernah mampir dalam hidupku, kemudian menggigiti seluruh rasaku. Aku seperti digelontorkan ke dalam lorong gelap yang menakutkan dan dipaksa untuk mendekam di dalamnya [a strange fear that never was part of my life tore all my senses. I felt like I was being pushed to the dark scary alley and was forced to stay in there]" (Krisdayanti and Endah 16). It is this feeling of confusion and fear that Krisdayanti claims to have urged her to somehow provide a more honest portrayal of herself and not the highly beautified image that she presented in the 2004 auto/biography. In the introduction of the second auto/ biography, she already comes clean about having been addicted to drugs, having had a plastic surgery, which she forcefully denied in the first auto/biography, as well as having had bitter conflicts with other entertainers. She said this honesty would free her to be at peace with her heart and become "a new person" (Krisdayanti and Endah 22).

The whole first chapter focuses on the mother's illness and its impacts. As Krisdayanti writes, the transformation of her mother from the very active to the relatively immobile person has caused a deep imbalance in her as she has always relied on her mother for a sense of tranquility and equilibrium. Even her marriage cannot shake off the bonding she has with her mother. As Krisdayanti is growing older and arguably wiser, she comes to realize even more the tight bonding between her and her mother. As she explains

Dibandingkan Yuni, ketergantunganku secara emosional pada Mama jauh lebih besar. Jika pada banyak anak perempuan lain, proses kedekatan dengan Ibu mereka

Kritika Kultura 33/34 (2019/2020): 214-225

(C) Ateneo de Manila University

<http://journals.ateneo.edu/ojs/kk/> 
akan berkurang sedikit demi sedikit seiring bergulirnya masa pernikahan mereka, tidak demikian dengan aku... Aku melakukan banyak hal dengan Mama. Berbelanja, menabung, bergosip, nonton sinetron, merujak, memasak, mencari makanan enak di pelosok Jakarta, mengecat kuku, memasang bulu mata palsu, senam, suntik kurus. Banyak hal. Mama memberi rasa aman yang begitu unik. Perpaduan antara sahabat, orang tua, dan preman sekaligus. Ya! Mama adalah orang pertama yang akan melabrak siapa pun yang mengusik aku, Yuni, atau Aie.

Compared to Yuni, my emotional dependence on my mother is so much bigger. While in the case of other daughters, their closeness with their mothers begin to diminish as they are engrossed in their own marriage, my case is different. I do so many things with Mama. Shopping, saving, gossiping, watching television dramas, having fruit salad, cooking, hunting for good food in the entire Jakarta, painting the nails, exercising, having slimming injection, installing fake eyelashes. So many things. Mama gives me a unique sense of security. A mixture of a good friend, a parent, and security a guard at the same time. Yes! Mama is always the first to counter anyone harassing me, Yuni, or Aie. (Krisdayanti and Endah 37)

This excerpt is interesting because it details a range of girly activities that Kridayanti and her mother share in a way that depicts them as friends and partners. It is also interesting because Krisdayanti uses the word "ketergantungan" which means "dependence." Working on the idea of embodiment by taking female embodiment as the norm, Christine Battersby argues that one consequence of the fact that we are being born is that we are dependent beings in a way that this dependency on our carers is normal and part of our humanity. This notion of our dependence on the mother, or her substitute, constitutes the "primary matrix... out of which we come to individuation" (Stone 169). Thus our separation from the mother will only be in a form of "continuous process of emergence from the 'intersecting force fields' of power-laden relations with others" (Stone 168).

On another note, we can also argue that the "dependence" as mentioned by Krisdayanti may refer to what Beauvoir claims as "intersubjectivity" because while she claims to be dependent on her mother, the mother also depends on her. In this way, both are subjects and, at the same time, both are objects. Within the discussion regarding the subject-object position, a relation of any kind, heterosexual or homosexual or the general "inter-human," to use Lundren-Gothlin's term (211), or even inter-sexual and intra-sexual in Gatens's terms (37), involves the desire to become a subject and to objectify. The fact is that one can only become a subject when one finds an object. One can only be Self when one is reflected by Other, and it makes the relations of Subject/Self and Object/Other unavoidable. However, de Beauvoir believes that the relation of two subjectivities does not necessarily objectify the other in a static mode. Rather, a relation is more of a dialectic that 
requires us to acknowledge each other's subjectivity and "recognize each other's as a free being" (Lundren-Gothlin 211). De Beauvoir believes that a harmony can actually be attained in the encounter of two consciousness provided there being "friendship and generosity" (Lundren-Gothlin 70).

Lundren-Gothlin provides a clearer understanding of de Beauvoir arguments. She depicts that as one consciousness needs the other to recognize oneself, one cannot exist without the other. She also points out that in de Beauvoir's approach, "one may experience the other as subject without experiencing oneself as object, so that conflict is not inevitable" (213-214). Taking into account the necessary "friendship and generosity," Lundren-Gothlin reminds us of the necessary element of equal relationship, as it is displayed by the relationship between Krisdayanti and her mother.

De Beauvoir acknowledges the potential conflict but then she argues that it does not mean that conflict is the only possibility of inter-human relation. This approach is also liberating because it provides a space in which even the constructed subject can actually experience being an object without losing his or her subjectivity. We would argue at this point that in term of independence and dependence, subject and object, to be independent a person needs to have a certain kind of freedom to be dependent. There is no such a thing as absolute freedom, or absolute independence or for the matter of discussion, an absolute subjectivity.

In this depiction, the mother and the daughter have reached a phase where mother and daughter are equal and are their own subject. Following Cixous, Paramaditha argues that mothering is not limited to simply caring for the offspring as it can be thought of in the more extensive understanding, mothering "means the love that a woman can give to herself, her child, and other women" (72). Here Krisdayanti's auto/biographies show that mothering exceeds the act of caring for one's child as it is also about loving one's mother, and more importantly, loving oneself. As Paramaditha exerts, elaborating Cixous, motherhood denotes selffulfillment as well as sisterhood.

We argue that the dynamic roles taken by the mother as shown in the excerpt are also made possible as the daughter has become a mother as well. The close bonding is established between mother and daughter as they come to understand each other better and to accept each other unconditionally. Rich describes,

Mothers and daughters have always exchanged with each other-beyond the verbally transmitted lore of female survival-a knowledge that is subliminal, subversive, preverbal: the knowledge flowing between two alike bodies, one of which has spent nine

Kritika Kultura 33/34 (2019/2020): 216-225

(C) Ateneo de Manila University

<http://journals.ateneo.edu/ojs/kk/> 
months inside the other. The experience of giving birth stirs deep reverberations of her mother in a daughter. (220)

Rich clearly explains how the experience of birthing have made mothers attuned to their daughters, enabling a more equal and balanced relationship, but also the ability to feel each other in a way that "knowledge flows between the two bodies." The instance mentioned in the second auto/biography during the time Yuni Shara experienced an abusive marriage reflects how mother and daughter embody two bodies as one. As Krisdayanti recalls,

Aku ingat bagaimana Mama selalu tak enak memasak, atau mendadak menghentikan makannya. "Mama ngerasa ada yang ngggak enak di hati," katanya. Ia mengaku selalu berpikiran tak baik tentang keadaan Yuni

I remember how Mama didn't feel like cooking, or suddenly stop eating her meals. "Mama feels there is something wrong," she said. She confessed to always feel there is something going wrong in Yuni's life.

The passage displays the close embodiment of mother-daughter relationship, the close proximity between the mother and the daughters that transcends the physical boundaries.

Yet the mother is described to respect her daughter's decision to stay in the marriage until an intolerable point has been crossed. She is quoted, "kalian sudah besar. Menikah adalah bukti kedewasaan. Mama harus menghargai pikiran dan keputuan yang muncul dari kedewasaan. Pada saatnya, jika dibutuhkan Mama akan bertindak [You're all grown up. Getting married is a proof of your maturity. I have to respect your ideas and decisions resulting from your adult mind. In time, when needed, I will do something about it]" (Krisdayanti and Endah 68).

As Kirkham proposes, one important virtue of motherhood is "liberality," and the mother in the auto/biography is exercising one important virtue deemed necessary for her daughter's understanding of her own life. Albeit keeping a safe distance from her daughter, she is watchful to ensure her daughter's safety. The same way is exerted as Yuni Shara underwent her second marital problems with her second husband. Despite the fact that her daughters are not young children anymore, through this liberality, the mother exercises her authority and at the same time reveals her love and care. In this particular depiction, we find the mother is again exercising complex and delicate roles of mothering where the mother embodies both the equal and the one holding the power and authority upon her daughters. 
In the first auto/biography, the mother is portrayed more as a provider and pillar of support in a way that depicts her as an ideal loving and caring mother. In the narrative of the second auto/biography, the mother is portrayed in a more complex way as it explores both her vulnerability and authority as well as the complexity of her relationship with her daughters. Maternal power over children, as Stone argues, is generally problematic and that daughters might never break away from her mother and "female subjects remain immured in dependency on their mothers... and remain embroiled in a lifelong and irresolvable struggle with autonomy, ever preoccupied with conflicts with and reliance upon their mothers" (170).

On the other hand, the mother's intervention in her daughters' life might be seen as the reluctance of the mother to be "killed" by her daughters. As Kristeva argues within the patriarchal framework, "matricide" is necessary a phase that children have to go through to gain their subjectivity and autonomy (Kristeva, 38). The idea of matricide implies that subjectivity and autonomy are achieved through the separation from the mother, which feminists such as Chodorow argue will never be accomplished by the daughter.

In Krisdayanti's second auto/biography, the sad occurrence of the mother's illness can be argued to constitute paths for Krisdayanti and her sisters to forge a new front and to rebuild the bonding among them and the mother, who is now relying on the daughters. This prompts a new dynamic of the mother-daughter relationship, where the roles of the mother and the daughter(s) are oscillating. Referring back to the definition of "mothering" as meeting the needs of the "children," the portrayal of mother-daughter relationships in the two auto/biographies brings a full circle where the daughters are now collectively mothering the mother. Just like new mothers, the daughters who are now playing the role of the mother to their mother are described to be very excited about every little progress their mother makes as the illness has put the mother in the position of a child under the care of her daughters who mother her,

Setelah itu, frekuensi telepon antara aku dan Yuni meningkat pesat. Bisa puluhan kali dalam sehari. Yuni mengabarkan apa saja tentang Mama. Mama sudah bisa mencoret kertas. Mama sudah bisa makan banyak. Mama sudah bisa tertawa lebar. Mama sudah bisa menonton TV. Dan, ini yang terpenting, Mama sudah bisa marah! Itu adalah kabar gembira. Aku merasa menemukan 'ibuku' kembali jika mendapatinya cerewet dan penuh emosi.

After that the frequency of the phone calls between Yuni and me increased drastically. It could be dozens a day. Yuni informed me anything about Mama. Mama had been able to make a scratch on the paper. Mama had managed to eat well. Mama had been able to laugh loudly. Mama had been able to watch TV. And, this is the most important thing.

Kritika Kultura 33/34 (2019/2020): 218-225 
Mama had been able to be angry! It was good news. I felt I had found 'my mother' back when she returned to her old self, nagging and emotional. (Krisdayanti and Endah 42)

The ability to show anger and emotion is signified as the return of her mother's agency and authority, things that have been greatly reduced as the body of the mother is weakened and immobilized. The joy the daughters share is not only the joy of the daughters finding back the mother but also finding their own capacity to mother the mother, which we argue to be the ultimate form of mothering. While the word "anger" might seem harsh, Kristeva has argued that during the semiotic period, children's ambivalence towards the mother includes the idea of the monstrous mother where mother represents both love and fear. Showing anger shows the particular element of motherhood that was missing in her mother at the time of her illness. On Krisdayanti's part as well as her sisters', re-experiencing the monstrous mother as the mother regains her strength can be perceived as experiencing the fullness of the ambivalent feelings of being mothered. This means the sign of the return of the mother as they know her.

In a subchapter entitled "Kasih yang murni [Pure love]," Krisdayanti has a retrospect, recalling her past and contextualizing it in the present as she tries to understand the significance of her mother's illness. She came to realize that the illness has enabled her to reconnect with her mother and her sister. As she narrates, "Aku melihat peristiwa sakitnya Mama adalah sinyal yang diberikan Tuhan bahwa telah ada yang hilang dari diri kami. Telah ada yang menguap dari jiwa kami, dan telah ada yang rontok dari nurani kami. Kebersamaan yang murni. Seperti dulu. [What I see from Mama's illness is a signal given by God that we have lost part of what we are. Our souls have pervaded, and we have certainly lost our conscience. Pure togetherness. Like we used to have before]" (72). Krisdayanti's reflection on her mother's illness suggests her recognition of what might be her sins and derailment from God's way. As having been discussed, in her second auto/ biography Krisdayanti was finally able to bring herself to confess the different "sins" and lies she had adamantly denied in her first auto/biography, including her doing drugs and having various cosmetic procedures. In dealing with the fate of her mother, therefore her own, the text suggests that Krisdayanti displays a sense of acceptance, "nrimo", that is (stereo)typically a Javanese value as well as the Islamic values of "ikhlas" - namely wholeheartedly accepting whatever is laid out to her by God.

On a different note, here again, the mother plays an important role in restoring the daughters' pure sisterhood, described to have been disrupted by their own respective marriages. The mother's illness has re-established what the daughters have lost through marriages. Mother-daughter relationship and sisterhood are delineated to be the purer, if not as the original form of relationship. 
The depiction of mother-daughter relationships in the two auto/biographies have also shown how the daughters as the subjects have not arrived at a fixed identity as Freud has suggested as an indication of achieving subjectivity and autonomy, rather the daughters continue to oscillate between the semiotics and the symbolic. They move away from the maternal body altogether but at the same time, they also maintain their close connection to it. Their subjectivity does not rely on their becoming separate(d) from the mother rather on the fact that they continue their process of becoming a subject. Kristeva coins this as "subject in process." Although Kristeva argues that continued identification with the mother would result in melancholia, the auto/biographies have so far displayed a positive and celebrated motherhood that has in fact empowered both the mother and the daughters (Black Sun).

\section{CONCLUDING NOTES}

In this article, we have shown how the mother-daughter relationship manifests in a mode of mothering that fits into what can be considered as "feminist mothering." While challenging the normative construction of motherhood, the two auto/ biographies display how motherhood has enabled the formation of the feminine as well as the feminist agency and subjectivity of the mother and the daughter(s). Rather than refuting the gendered attributes of motherhood, the auto/biographies embrace and celebrate the feminine attributes of motherhood and reclaim it as feminist mothering. It also suggests the dynamics in the way that the function of "mothering" as meeting the needs is not only conducted by the mother towards the daughters but also the daughters towards their mother. The two auto/biographies delineate motherhood that transcends its construction as an institution and shifts it into feminist undertaking and practices, particularly as it manifests in partnership and sisterhood. The two auto/biographies explicate motherhood as an empowering experience, celebrated by the mothers and the daughters alike, establishing the formation of subjectivity and agency that eludes the fixed identity and roles.

Covering different periods and written in different approaches, the two auto/ biographies reveal gaps and ruptures pertaining not only the construction of celebrity motherhood, particularly with regard to the mother-daughter relationships but also the narrative of celebrity auto/biographies. The texts present and embrace various narratives that are not always consistent with each other, which we take as elements contributing to the representation of celebrity motherhood, that is not necessarily cohesive and stable. The two texts act as a dialogue between different representations of female celebrities, motherhood and mother-daughter 
relationship, which albeit the contradictions reflects a feminist construction of self that is contingent and even fragmented.

We are closing this article by quoting Rich's important work on motherhood and daughterhood: "We need to understand this double vision or we shall never understand ourselves. Many of us were mothered in ways we cannot yet even perceive; we only know that our mothers were in some incalculable way on our side" (225). Rich reminds us the need to tell the stories of mothering because the mothers' stories are often sidelined and pushed aside. By putting forward the narrative of mothering as a form of feminist project, our discussion on mothering celebrities has exhibited that while motherhood alludes contradictions, it also engenders joy and empowerment. More importantly, citing Green, (feminist) mothering creates the potentiality for social transformation, particularly in the context of gender ideology and construction. 


\section{Note}

1. All texts in Bahasa Indonesia included are translated by the authors of this article.

Kritika Kultura 33/34 (2019/2020): 222-225

(c) Ateneo de Manila University <http://journals.ateneo.edu/ojs/kk/> 


\section{Works Cited}

Astuti, Tri Marhaeni P. “Gerakan Tandingan Perempuan: Kasus Migrasi Perempuan Kelas Bawah Di Grobogan, Jawa Tengah.” Perempuan Indonesia Dalam Masyarakat Yang Tengah Berubah, edited by E. Kristi Poerwandari and Rahayu Surtiati Hidayat, Women's Studies Graduate Program, Universitas Indonesia, 2000, pp. 493-515.

Bartky, Sandra Lee. "Foucault, Femininity, and the Modernization of Patriarchal Power." Writing on the Body: Female Embodiment and Feminist Theory, edited by Katie Conboy, Nadia Medina, and Sarah Stanbury, Columbia UP, 1997, pp. 93-111.

Battersby, Christine. The Phenomenal Woman - Feminist Metaphysics and the Patterns of Identity. Polity Press, 1998.

Bhisma, Mahardian Prawira. "Lima Bulan Tak Bertemu Kd, Aurel Ungkap Kekecewaan Di Instagram." DetikHot, 31 Aug. 2015, https://hot.detik.com/celeb/3005212/ lima-bulan-tak-bertemu-kd-aurel-ungkap-kekecewaan-di-instagram.

Brenner, Suzanne April. The Domestication of Desire: Women, Wealth, and Modernity in Java. Princeton UP, 1998.

Brodzki, Bella, and Celeste Schenck. Theorizing Women's Autobiography. Cornell UP, 1988.

Bruner, Jerome. "The Autobiographical Process." The Culture of Autobiography: Constructions of Self-Representation, edited by Robert Folkenflik, Stanford UP, 1993, pp. 38-56.

Chodorow, Nancy. The Reproduction of Mothering : Psychoanalysis and the Sociology of Gender. U of California P, 1978.

Cixous, Helene. "The Laugh of the Medusa." New French Feminisms: An Anthology, edited by Elaine Marks and Isabelle deCourtivron, Schocken Books, 1981, pp. 245-264.

Cosslett, Tess, Celia Lury, and Penny Summerfield. Feminism and Autobiography: Text, Theories, Methods. Routledge, 2000.

de Beauvoir, Simone. The Second Sex. Knopf Doubleday, 2012.

Djajadiningrat-Nieuwenhuis. "Ibuism and Priyayization: Path to Power?" Indonesian Women in Focus: Past and Present Notions, edited by Elsbeth Locher-Scholten and Anke Niehof, Foris, 1987, pp. 42-51.

Douglas, Susan J., and Meredith W. Michaels. The Mommy Myth: The Idealization of Motherhood and How It Has Undermined Women. Free Press, 2004.

Dyer, Richard. Stars. British Film Institute Publishing, 2001.

Endah, Alberthiene. Seribu Satu Kd. Gramedia Pustaka Utama, 2004.

Gatens, Moira. Imaginary Bodies: Ethics, Power, and Corporeality. Routledge, 1995,

Geraldine, Tamara and Darwis Triadi. Yuni Shara: 35 Cangkir Kopi. Gramedia Pustaka Utama, 2007.

Green, Fiona J. Feminist Mothering in Theory and Practice: 1985-1995. A Study in Transformative Politics. Mellen, 2009.

Hays, Sharon. The Cultural Contradictions of Motherhood. Yale UP, 1998.

Jelinek, Estelle C. Women's Autobiography: Essays in Criticism. Indiana, UP, 1980. 
Kirkham, Nin. "The Virtues of Motherhood." Motherhood Philosophy for Everyone: The Birth of Wisdom, edited by Sheila Lintott, Wiley-Blackwell, 2010, pp. 180-19o.

Krisdayanti, and Alberthiene Endah. My Life, My Secret: Catatan Hati Krisdayanti. Gramedia Pustaka Utama, 2009.

Kristeva, Julia. Black Sun: Depression and Melancholia. Columbia UP, 1992.

--. Desire in Language : A Semiotic Approach to Literature and Art. Edited by Leon Roudiez. Translated by Thomas Gora and Alice Jardine. Columbia UP, 1980.

--. "Motherhood According to Giovanni Bellini." Desire in Language - a Semiotic Approach to Literature and Art, Basil Blackwell, 1980.

Lagerwey, Jorie. Postfeminist Celebrity and Motherhood: Brand Mom. Routledge, 2017. Lawler, Steph. Mothering the Self: Mothers, Daughters, Subjects. Routledge, 2000.

Lundren-Gothlin, Eva. Sex and Existence: Simone De Beauvoir's the Second Sex. The Athlone Press, 1996.

O'Reilly, Andrea. From Motherhood to Mothering: The Legacy of Adrienne Rich's of Woman Born. State U of New York P, 2004.

-.. "The Motherhood Memoir and the "New Momism": Biting the Hand That Feeds You." Textual Mothers / Maternal Texts: Motherhood in Contemporary Women's Literatures, Wilfrid Laurier UP, 2010, pp. 203-213.

Paramaditha, Intan. “Tracing the White Ink: The Maternal Body in Indonesian Women's Writing." Review of Indonesian and Malaysian affairs Review of Indonesian and Malaysian Affairs, vol. 41, no. 2, 2007, pp. 67-94.

Pemita, Desika. "Jadi Ibu Tiri, Ini 6 Bukti Ashanty Justru Sangat Menyayangi Aurel Dan Azriel." 26 July 2018, https://www.liputan6.com/showbiz/read/3600787/ unggah-foto-seksi-aurel-hermansyah-kena-omel-ashanty-dan-anang.

Peterson, Linda H. "Institutionalizing Women's Autobiography: Nineteenth-Century Editors and the Shaping of an Autobiographical Tradition." The Culture of Autobiography: Constructions of Self-Representation, edited by Robert Folkenflik, Stanford UP, 1993, pp. 80-103.

Prabasmoro, Aquarini Priyatna. Staging a Life: Portraying Femininities in the Auto/ Biographies of Indonesian Female Celebrities. Monash University, 2011.

Priyatna, Aquarini. Becoming White: Representasi Ras, Kelas, Femininitas Dan Globalitas Dalam Iklan Sabun. Matahari, 2013.

--. "Fragments and Coherence: Celebrity Femininities in Cover Story of Kartini Magazine." Humaniora, vol. 29, no. 2, 2017, pp. 127-139.

Redmond, Sean. "Intimate Fame Everywhere." Framing Celebrity: New Directions in Celebrity Culture, edited by Sue Holmes and Sean Redmond, Routledge, 2006, pp. 27-44.

Rich, Adrienne Cecile. Of Woman Born: Motherhood as Experience and Institution. Norton, 1995.

Robinson, Sally. Engendering the Subject: Gender and Self-Representation in Contemporary Women's Fiction. State U of New York P, 1991.

Smith, Sidonie, and Julia Watson. Women, Autobiography, Theory: A Reader. The U of Wisconsin P, 1998. 
Smith-Hefner, Nancy J. "The Domestication of Desire: Women, Wealth, and Modernity in Java: The Domestication of Desire: Women, Wealth, and Modernity in Java." American Anthropologist American Anthropologist, vol. 101, no. 4, 1999, pp. 877-878.

Stanley, Liz. The Auto/Biographical I: The Theory and Practice of Feminist Auto/Biography. Manchester UP, 1992.

Stone, Alison. "Female Subjectivity and Mother-Daughter Relations." Women: A Cultural Review, vol. 22, nos. 2-3, 2011, pp. 168-179.

Sunindyo, Saraswati. "Murder, Gender, and the Media: Sexualizing Politics and Violence." Fantasizing the Feminine in Indonesia, edited by Laurie J. Sears, Duke UP, 1996, pp. 120-139.

Suryakusuma, Julia I. State Ibuism: The Social Construction of Womanhood in New Order Indonesia. Foreword by David Reeve and Robert Cribb. Komunitas Bambu, 2011.

Tong, Rosemarie. Feminist Thought: A More Comprehensive Introduction. Westview Press, 1989.

Kritika Kultura 33/34 (2019/2020): 225-225

(c) Ateneo de Manila University

<http://journals.ateneo.edu/ojs/kk/> 